\title{
Bacterial Assessment of Buffalo Meat in Kathmandu Valley
}

\author{
Barsha Koirala $^{1 *}$, Radha Bhattarai ${ }^{1}$, Rashmi Maharjan ${ }^{1}$, Sanjeet Maharjan ${ }^{1}$ and Shova Shrestha \\ ${ }^{1}$ Department of Microbiology, Tri - Chandra Multiple Campus, Kathmandu
}

\section{*CORRESPONDENCE: \\ Barsha Koirala \\ Department of Microbiology, Tri - \\ Chandra Multiple Campus, Kathmandu \\ Email: varshakoirala@gmail.com.}

ISSN : 2382-5359(Online), 1994-1412(Print)

DOI:

https://doi.org/10.3126/njst.v20i1.39438

\section{ACCESS THE ARTICLE ONLINE}

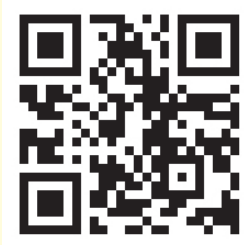

\section{CONFILICT OF INTEREST: None}

Copyright: The Author(s) 2019. This is an open

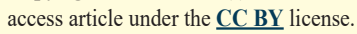

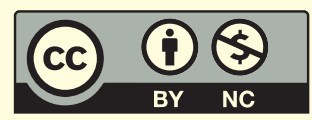

\begin{abstract}
Meat is highly nutritious and mostly consumed food. Usually, meat gets contaminated because of improper handling, open transportation practice, unhygienic cutting tools, and can cause various food-borne illnesses. This study was focused to determine bacterial load and occurrences of potential pathogenic bacteria in the raw buffalo meat sold in Kathmandu valley. Altogether 40 raw buffalo meat samples were collected and assessed. In addition, antibiotic susceptibility of gramnegative bacterial isolates was tested. The total plate count (TPC), and coliform count (CC) in the samples were found comparatively highest from the Asan area of Kathmandu with 9.6 $\pm 0.02 \mathrm{log}$ CFU/gm and $8.9 \pm 0.00 \log \mathrm{CFU} / \mathrm{gm}$ respectively. Altogether 10 genera of gramnegative bacteria were identified based on the various biochemical tests. The isolated gram-negative bacteria included Proteus spp (39\%, 21/54), Pseudomonas (19\%, 10/54) Citrobacter spp. (9\%, 5/54), E. coli $(7 \%, 4 / 54)$, Serratia marcescens (5\%, 3/54), Salmonella spp. (9\%, $5 / 54)$, Enterobacter spp. (2\%,1/54), Morganella morganeii $(2 \%, 1 / 54)$, Klebsiella $(2 \%, 1 / 54)$, Yersinia enterocolitica $(6 \%, 3 / 54)$. The antibiotic susceptibility tests for the isolates was carried against six different antibiotics including-Ofloxacin (OF), Ciprofloxacin (CIP), Nalidixic Acid (NA), Nitrofurantoin (NIT 300), Amoxycillin (AMX) and Chloramphenicol (C). Out of total 54 isolates, 36 were found to be multidrug- resistant. The results of this study clearly revealed buffalo meat sold in Kathmandu valley was contaminated with potential bacterial pathogens which may cause various food- borne illnesses. The occurrence of multi - drug resistant bacteria in the meat samples is alarming threat to public health. Adequate measures to protect bacterial contamination in buffalo meat is highly recommended.
\end{abstract}

Keywords: Buff meat, gram-negative bacteria, AST

\section{INTRODUCTION}

Since ancient times, people domesticate animals like chicken, sheep, pig, buffalo, goat, and consume them as meat (Lawrie et al. 2006). Meat is nutritionally rich food composed of water, protein and amino acids, minerals, fats, fatty acids, vitamins, bioactive components, and carbohydrates (Charlton et al. 2008). Because of these nutritional varieties in meat, it is one of the better mediums for microbial contamination. Enterobacteriaceae are a large family of gram-negative bacteria that includes Salmonella, Escherichia coli, Yersinia pestis, Klebsiella, Shigella, Proteus, Enterobacter, Serratia, and Citrobacter. They are also called enterobacteria or enteric bacteria, as various members of this family are the gut flora found in the intestines of humans and other animals, while others are found in water or soil, or are parasites on 
a variety of different animals and plants (Williams et al. 2010). Food- borne infection is caused by the ingestion of food contaminated with microorganisms and the reaction of the body to their presence or their metabolites. Examples include Salmonellosis, Cholera. Likewise, Food intoxication is caused by ingesting food containing preformed toxins. Examples include-Staphylococcal Intoxication (Enterotoxin), botulism (neurotoxin) (Gwida et al. 2014; Frazier \& Westhoff 1988). The nature and level of microbial contamination in meat have a necessary consequence on public health, storage life, and the type of spoilage of meat. The rearing, slaughtering, and processing condition of meat are essential factors for determining the microbial contamination in meat (Brown \& Parker 1982).

Meat is a shelter for many organisms because of its moisture content, nutritious values, and various growth factors. The microorganism can contaminate meat from external sources like unhygienic bleeding, improper handling and processing, exterior parts of animals- like skin, hairs, soil, water, feed and manure, natural surface flora. Considering poor hygiene and other factors, we hypothesize that raw Buffalo meat might be contaminated with potential pathogenic gram- negative bacteria. Since the Buffalo meat consumption is higher in Kathmandu, the maintenance of its quality should be the priority. This study is carried out to understand the occurrence of microbial potential pathogens which may indicate possible incidence of foodborne illnesses. The study also describes the antibiotic susceptibility test pattern of the contaminants along with frequency of multiple antibiotic resistant bacteria. The study provides information on bacteriological quality of buffalo meat from different parts of Kathmandu Valley.

\section{MATERIALS AND METHODS}

\subsection{Collection of Samples}

Total 40 raw meat samples (flesh) of Buffalo, each weighing 25 grams were collected from local markets of Kathmandu valley (Asan, Gongabu, Kalanki, Kirtipur, Godawari, Patan, Bhaktapur city \& Thimi) in the month of August. The samples were collected in sterile Zip lock polyethylene bags in the morning hours and transported to the laboratory for analysis and processed immediately. The microbiological assessment of the meat samples was conducted at Research Laboratory for Biochemistry and Biotechnology (RLABB), Kathmandu.

\subsection{Laboratory Analysis}

Total bacterial count and coliform count was determined by heterotrophic plate count and pour plate technique using plate count agar (PCA) and violet red bile salt agar
(VRBA) media respectively (Feng et al. 2002, Prathab and Lalitha 2012). Selected gram-negative bacteria were isolated on respective media and identified by standard microbiological techniques, and their antibiotic susceptibility Test (AST) was done by Kirby-Bauer disc diffusion method.

\subsubsection{Heterotrophic Plate Count and Coliform Count}

Total $225 \mathrm{ml}$ of sterilized buffer peptone water (BPW) and $25 \mathrm{gm}$ of raw meat sample were mixed at $80 \mathrm{rpm}$ for 30 minutes and diluted to the required dilutions (USFDA 2012). For the pour plate, $1 \mathrm{ml}$ of meat homogenate from appropriate dilutions was transferred to sterile Petri dishes, on which molten media were poured (PCA \& VRBA for heterotrophic and coliform count, respectively) and then mixed gently. The inoculated plates were incubated at $37^{\circ} \mathrm{C}$ for 24 hours. The isolated colonies on the plates were counted.

\subsubsection{Isolation and Identification of Bacteria}

Since gram negative-bacteria were targeted in this study, isolated selected colonies from VRBA media were purified to recover coliform bacteria. However, raw meat homogenate was enriched for 24 hours at $37^{\circ} \mathrm{C}$ in Selenite Broth $(1: 10)$ and alkaline peptone water $(1: 10)$ to isolate Salmonella, Shigella and Vibrio species (Shrestha et al. 2017). Further isolation of bacteria was done on Xylose Lysine Deoxycholate (XLD) agar and Thiosulfate-citratebile salts-sucrose(TCBS) agar incubating at $37^{\circ} \mathrm{C}$ for 24 hours (Da Silva et al. 2013). Typical colonies grown on the media were purified on Nutrient Agar (NA) and lactose fermenting bacteria were distinguished on MacConkey Agar (MA) (Frazier \& Westhoff 1988; Sharma et al. 2015). The isolates were then identified using microbiological techniques as colony morphology, Gram's staining, and biochemical properties. Only gram-negative cultures were selected for further identification using catalase, oxidase, indole production, methyl red, Voges-Proskauer, motility, citrate utilization, triple sugar iron agar, urea hydrolysis and oxidation-fermentation tests (Happy et al. 2018; Shrestha 2009).

\subsubsection{Antibiotic Susceptibility Test}

Antibiotic susceptibility testing was performed by the Kirby Bauer disc diffusion method on Mueller-Hinton agar (MHA) as recommended by the Clinical Laboratory Standard Institute (CLSI 2020) guidelines. In this technique, a test organism inoculum in nutrient broth following 4 hours incubation at $37{ }^{\circ} \mathrm{C}$ was adjusted to the turbidity equivalent to $0.5 \mathrm{McF}$ arland scale and carpet cultured on MHA. The antibiotic discs were laid over the 
carpet culture on the media. After overnight incubation, the clear zone size around the disc was measured, and the result was interpreted according to the standard zone size interpretative chart (Frazier \& Westhoff 1988) as CLSI (2020) guidelines. Antibiotics used in this study were Ciprofloxacin, Ofloxacin, Nalidixic Acid, Nitrofurantoin, Amoxycillin, and Chloramphenicol (Gautam et al. 2018) which were also purchased from Hi-media laboratory Pvt. Ltd. India.

\subsubsection{Quality Control}

The performance of laboratory equipment including -incubator, refrigerator and autoclave was assessed periodically during the study period. Control was used for every media prepared to check the contamination during the media preparation (King \& Brown 2001). Purity plate technique was applied to avoid any misleads due to contaminants. Performance of each media and antibiotic disc was maintained with parallel experiments using standard American type culture collection strains as per the recommendations.

\subsubsection{Data Analysis}

The results were carried out in triplicates and expressed as mean \pm S.D. The one-way ANOVA was performed and the $p$-value less than 0.05 were considered to be statistically significant.

\section{RESULTS AND DISCUSSION}

Buffalo meat in Nepal is almost consumed without proper washing because of some religious taboos. Buffaloes are slaughtered at the slaughterhouse and transported to the different local vendors. The slaughterhouses of Nepal do not follow the hygienic process for meat processing. Meat is then transported using a rickshaw or small vehicles without proper covering responsible for the bacterial contamination compared to the Isolation obtained by the investigators from other parts of the world where hygienic practices are maintained during the meat processing (Adhikari et al. 2012). The main objective of this study was to understand the microbial quality of raw buffalo meat sold in Kathmandu Valley of Nepal.

In this study, the total plate count (TPC) and coliform count (CC) of 40 raw buff meat samples from Kathmandu valley were assessed and the results are presented in Table 1. As shown in the table 1 , the average total plate count for raw buffalo meat was found to be somewhat similar to the findings of Ayten et al. (2014) and Baskaya et al. (2004) who reported $6.36 \mathrm{log} \mathrm{CFU} / \mathrm{gm}$ and $6.14 \mathrm{log} \mathrm{CFU} / \mathrm{gm}$, respectively. However, the results in this study were lower than the finding of the Adhikari et al. (2012) who reported $7.55 \log$ CFU/gm, and higher than Kandeepan et al. (2011), Siddiqui and Harsojo, and Sari (2015) whose findings were 3.52, 3.58, and $5.87 \log$ CFU/gm, respectively.

Various researchers from different parts of the world have enumerated coliform bacteria in meat samples and have reported in range of 4.15 - $5.09 \mathrm{log} \mathrm{CFU} / \mathrm{gm}$ (Harsojo \& Sari 2015; Ayten et al. 2014; Baskaya et al. 2004; Daly et al. 1976). In contrast to these reports, we found higher values of the average coliform count in raw buffalo meat samples (Table 1). These differences in total count might be because of the seasonal differences of the sample collection, practices of hygiene in the slaughterhouse, meat from the different body parts of buffalo and so on.

Table 1: Total Plate Count (TPC) and Coliform Count (CC) in buff meat

\begin{tabular}{|l|l|c|c|}
\hline \multicolumn{2}{|c|}{ Name of districts and local area } & \multicolumn{2}{|c|}{ Chicken meat microbial load (log cfu/gm) } \\
\cline { 2 - 4 } \multicolumn{1}{|l}{} & Total Plate Count (TPC) & Coliform Count (CC) \\
\hline Kathmandu & 1.Asan & $9.6 \pm 0.02$ & $8.9 \pm 0.00$ \\
& 2. Gongabu & $8.2 \pm 0.09$ & $7.2 \pm 0.15$ \\
& 3. Kalanki & $7.5 \pm 0.00$ & $3.9 \pm 0.00$ \\
& 4. Kirtipur & $4.1 \pm 0.10$ & $3.5 \pm 0.02$ \\
\hline Bhaktapur & 1.Bhaktapur city & $8.2 \pm 0.00$ & $8.1 \pm 0.09$ \\
& 2. Thimi & $7.3 \pm 0.01$ & $7.2 \pm 0.43$ \\
& & & $4.5 \pm 0.03$ \\
\hline Lalitpur & 1.Patan & $5.2 \pm 0.05$ & $3.9 \pm 0.21$ \\
& 2. Godawari & $4.8 \pm 0.24$ & \\
\hline
\end{tabular}

All the values were expressed as mean \pm standard deviation and found to be statistically significant $(p<0.05)$

The presence of coliforms in meat products is the indication of improper techniques that are being used during preparation, handling, processing, and temperature of holding. The contamination may be from water too. Therefore, it is necessary to use good water quality to avoid contamination (Vanderlinde et al. 1998).Coli forms are present in the gut of warm-blooded animals. They are an indicator for fecal pollution and unsanitary condition of meat and meat products, and their presence indicates enteropathogenic and toxigenic microorganisms that constitute a public health hazard and economic loss (Morshidy \& Roushdy1983).

In this study, we isolated and identified ten different genera of gram-negative bacteria from raw buffalo meat samples. The identification was based on biochemical properties of the isolates (Table 2). 
Table 2: Results for Biochemical tests for isolates

\begin{tabular}{|c|c|c|c|c|c|c|c|c|l|}
\hline \multirow{2}{*}{ Ox } & \multirow{2}{*}{ Cit } & Mot & \multirow{2}{*}{ Ind } & \multirow{2}{*}{ Urea } & \multicolumn{4}{|c|}{ TSIA } & \multicolumn{2}{l|}{ Bacterial Species } \\
\cline { 5 - 10 } & & & & & Slope & Butt & H2 & Gas & \\
\hline- & - & + & + & - & $\mathrm{Y}$ & $\mathrm{Y}$ & - & + & Escherichia coli \\
\hline- & - & + & - & - & $\mathrm{R}$ & $\mathrm{Y}$ & + & - & Salmonella Typhi \\
\hline- & + & - & - & + & $\mathrm{Y}$ & $\mathrm{Y}$ & - & + & Klebsiella spp. \\
\hline- & + & + & - & - & $\mathrm{Y}$ & $\mathrm{Y}$ & - & + & Enterobacter spp. \\
\hline- & + & + & + & + & $\mathrm{R}$ & $\mathrm{Y}$ & + & + & Proteus spp. \\
\hline- & - & + & + & + & $\mathrm{R}$ & $\mathrm{Y}$ & - & + & Morganella morganeii \\
\hline+ & + & + & - & + & $\mathrm{R}$ & $\mathrm{R}$ & - & - & Pseudomonas spp. \\
\hline- & + & + & - & + & $\mathrm{R}$ & $\mathrm{Y}$ & - & - & Serratia marcascens \\
\hline- & - & + & + & + & $\mathrm{R}$ & $\mathrm{Y}$ & - & - & Yersinia enterocolitica \\
\hline
\end{tabular}

$\left(\mathrm{Ox}=\right.$ oxidase test, $\mathrm{Cit}=$ Citrate test, Mot=Motility, Ind=Indole test, $\mathrm{H}_{2} \mathrm{~S}=$ Hydrogen sulphide, $\mathrm{R}=\mathrm{Red}-\mathrm{Pink}$ (alkaline reaction), $\mathrm{Y}=$ Yellow (acid reaction, $+=$ positive, $-=$ negative)

Besides coliform genera, the presence of Salmonella Typhi, Yersinia enterocolitica and other potential pathogens in the raw buffalo meat samples was found in this study. Salmonella is found anywhere in nature, including the digestive tracts of different animals, poultry products, milk products, and seafood. The nature and level of microbial contamination in meat have a necessary consequence on public health, storage life and the type of spoilage of meat. The rearing, slaughtering, and processing condition of the meat determines its microbiology. The extent to which the contamination occurs, and the flora's composition reflect the hygiene standard (Brown \& Parker 1982).

The most frequent bacteria contaminating meat samples was Proteus species, followed by Pseudomonas, Salmonella and Citrobacter species (Figure 1).

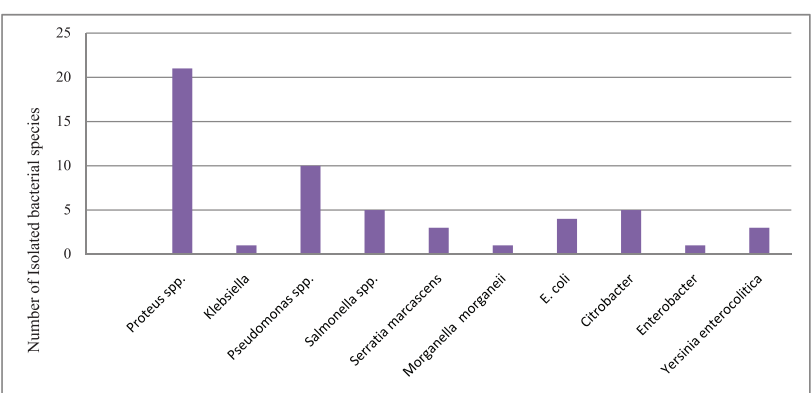

Fig. 1. Total isolates of the organism from buff meat

The equal sample size was taken for the analysis from three different districts namely Kathmandu, Bhaktapur, and Lalitpur. However, the highest microbial count and micro- organisms were isolated from the Kathmandu district (Table 3). This implies that compared to Bhaktapur and Lalitpur, meat vendors in Kathmandu are less conscious regarding sanitation and hygiene.

Table 3: Distribution of isolated organism in the districts (Kathmandu, Bhaktapur \& Lalitpur) of Kathmandu valley

\begin{tabular}{|c|c|c|c|}
\hline Name of bacteria & \multicolumn{3}{|c|}{$\begin{array}{l}\text { Distribution of isolated organisms in } \\
\text { different districts }\end{array}$} \\
\hline & Kathmandu & Bhaktapur & Lalitpur \\
\hline Proteus spp. & 12 & 4 & 5 \\
\hline Klebsiella & 1 & - & - \\
\hline Pseudomonas spp. & 4 & 4 & 2 \\
\hline Salmonella spp. & 1 & 2 & 2 \\
\hline Serratia marcascens & 1 & 1 & 1 \\
\hline Morganella morganeii & 1 & - & - \\
\hline E. coli & 2 & 1 & 1 \\
\hline Citrobacter & 2 & 1 & 2 \\
\hline Enterobacter & 1 & - & - \\
\hline Yersinia enterocolitica & 1 & - & 2 \\
\hline Total & 26 & 13 & 15 \\
\hline
\end{tabular}

All the organisms isolated from both meat samples were subjected to antibiotic susceptibility test by using the KirbyBauer disc diffusion method using different antibiotic discs- Ofloxacin (OF), Ciprofloxacin (CIP), Nalidixicacid (NA), Nitrofurantoin (NIT 300), Amoxycillin (AMX) and Chloramphenicol (C). The isolates were differentiated as susceptible or resistant by measuring the inhibition zone concerning zone size interpretative chart (Table 4). 
Table 4: Antibiotic susceptibility test of various isolates

\begin{tabular}{|l|c|c|c|c|c|c|c|}
\hline \multicolumn{1}{|c|}{ Name of organism } & No. of isolates & \multicolumn{3}{c|}{ Frequency of resistant isolates (percentage) against different antibiotics } \\
\hline & & AMX & C & CIP & NA & NIT & OF \\
\hline Proteus spp. & 21 & $18(85.72)$ & $16(76.20)$ & $11(52.39)$ & $16(76.20)$ & $16(76.20)$ & $14(66.67)$ \\
\hline Klebsiella & 1 & $1(100)$ & - & - & $1(100)$ & $1(100)$ & $1(100)$ \\
\hline Pseudomonas spp. & 10 & $1(10)$ & $5(50)$ & $2(20)$ & $2(20)$ & $8(80)$ & $7(70)$ \\
\hline Salmonella spp. & 5 & $3(60)$ & $3(60)$ & - & $3(60)$ & $3(60)$ & $5(20)$ \\
\hline Serratia marcescens & 3 & - & $1(33.33)$ & - & $1(33.33)$ & $1(33.33)$ & $1(33.33)$ \\
\hline Morganella morganeii & 1 & $1(100)$ & - & - & & $1(100)$ & - \\
\hline E. coli & 4 & $2(50)$ & - & - & $3(75)$ & - & - \\
\hline Citrobacter & 5 & $3(60)$ & $1(20)$ & - & - & - & - \\
\hline Enterobacter & 1 & - & - & $1(100)$ & $1(100)$ & - & - \\
\hline Yersinia enterocolitica & 3 & $2(66.66)$ & $3(100)$ & $2(66.66)$ & $2(66.66)$ & $2(66.66)$ & $1(33.33)$ \\
\hline
\end{tabular}

The figures in parentheses indicate the percentage

All the organisms isolated from both meat samples were subjected to antibiotic susceptibility test by using the Kirby-

Bauer disc diffusion method using different antibiotic discs-Ofloxacin (OF), Ciprofloxacin (CIP), Nalidixicacid (NA), Nitrofurantoin (NIT300), Amoxycillin (AMX) and Chloromphenicol $(\mathrm{C})$. The isolates were differentiated as susceptible or resistant by measuring the inhibition zone concerning zone size interpretative chart (Table 5).

Out of 54 isolates, 36 isolates of Gram-negative bacteria were found to be resistant to the multiple antibiotics (MDR) (Table 6). Total Multiple Drug-resistant bacteria can cause serious health problems directly or by transferring traits (Doyle \& Ericson 2006). Those traits can be circulated to the environment through animal wastage. The MDR for the isolated microorganism from the raw buffalo meat might be due to the prolonged use or overdose/misuse of antibiotics in animal farms as growth promoters. The use of antibiotics can prevent it as directed and in a low dose. The animal should be given antibiotics only in the diseased condition, and Antibiotic-free policies for meat supplies needs to be made (Economou \& Gousia 2015).

Table 5: Multiple Drug Resistant (MDR) pattern of isolated organisms

\begin{tabular}{|l|c|c|c|c|}
\hline \multirow{2}{*}{ Bacteria } & \multicolumn{2}{|c|}{ MDR } & \multicolumn{2}{c|}{ No MDR } \\
\cline { 2 - 5 } & $\begin{array}{c}\text { Number of } \\
\text { isolates }\end{array}$ & $\%$ & $\begin{array}{c}\text { Num- } \\
\text { ber of } \\
\text { isolates }\end{array}$ & $\%$ \\
\hline Proteus spp. & 16 & 76.19 & 5 & 23.81 \\
\hline Klebsiella & 1 & 100 & - & - \\
\hline Pseudomonas spp. & 7 & 70 & 3 & 30 \\
\hline Salmonella spp. & 3 & 60 & 2 & 40 \\
\hline Serratia marcescens & 1 & 100 & 2 & - \\
\hline Morganella morganeii & 1 & 100 & - & - \\
\hline
\end{tabular}

\begin{tabular}{|l|c|c|c|c|}
\hline E. coli & 2 & 50 & 2 & 50 \\
\hline Citrobacter & 2 & 40 & 3 & 60 \\
\hline Enterobacter & 1 & 100 & - & - \\
\hline Yersinia enterocolitica & 2 & 66.67 & 1 & 33.33 \\
\hline Total & 36 & & 18 & \\
\hline
\end{tabular}

\section{CONCLUSION}

Altogether, 10 genera of Gram-negative bacteria (Salmonella, Shigella, Escherichia coli, Proteus, Yersinia, Klebsiella, Pseudomonas, Citrobacter, Enterobacter, Morganella, were isolated from buffalo meat samples from three different districts of Kathmandu valley. Among 54 isolated organisms, 36 isolates were found to be MDR positive.

\section{ACKNOWLEDGEMENT}

We would like to acknowledge Ms. Rama Khadka for her continuous guidance and RLABB for providing us lab for research work.

\section{REFERENCES}

1. Adhikari, B.M., R.P. Subedi and D. Subba, 2012.A study on standard of buffalo meat hygiene in Dharan. J Food Sci and Technol Nepal 7: 98-101.

2. Ayten, K.E., S. Duygu, O. Didem, and O. Ezgi, 2014. Microbiological quality of minced meat samples marketed in Istanbul.Y.Y.U. Veteriner Falkutesi Dergisi 25: $67-70$

3. Baskaya, R., T. Karaca, I. Sevinç, O. Çakmak, A. Yıldız and M. Yör. 2004. Istanbul'dasatisasunulanhazirkiymalarinhistolojik, 
mikrobiyolojikveserolojikkalitesi YYU Vet FakDerg 15: 41-46.

4. Brown, M.H. and A.C.B. Parker. 1982. The Microbiological Examination of Meat, In. Meat Microbiology, Brown MH Applied Science. P 529.

5. Charlton, K.E., Y.C. Probst, L.C. Tapsell, and P.J. Blackall. 2008. Food health and nutrition: Where does chicken meat fit? ACMF Ins 71:235-239.

6. CLSI. 2020. Performance Standards for Antimicrobial Susceptibility Testing. $30^{\text {th }}$ ed. CLSI Supplement M100. Wayne, PA: Clinical and Laboratory Standards Institute.

7. Daly, M.C., P.A. Morrissey and Buckley, D.J. 1976. Quality of raw minced beef. Ir J Agric Res 5: 280-283.

8. Da Silva, D.C.F., A.M.V. De Arruda and A.A. Gonçalves. 2017. Quality characteristics of broiler chicken meat from free-range and industrial poultry system for the consumers. J Food Sci Technol 54: 1818-1826.

9. Doyle, M.P. and M.C. Erickson. 2004. Emerging microbiological food safety issues related to meat. Meat Sci 74:98-112.

10. Economou, V. and P. Gousia. 2015. Agriculture and food animals as a source of antimicrobial-resistant bacteria. Infection and drug resistance 8: 49-61. https://doi.org/10.2147/IDR.S55778

11. Feng, P., S.D. Weagant, M.A. Grant, W. Burkhardt, M. Shellfish and B. Water. 2002. B.A.M.: enumeration of Escherichia coli and the coliform bacteria. Bacteriological analytical manual, pp 13-19.

12. Food, U. and D. Administration. 2012. Bacteriological analytical manual, chapter 1, Food sampling/ Preparation of sample homogenate. Science and Research (Food). Pp 1-10.

13. Frazier, W.C. and D.C.Westhoff. 1998. Food Microbiology. $4^{\text {th }}$ edition. Tata McGraw Hills Publishing Company Limited. p 218.

14. Gautam, N., R. Poudel, B. Lekhak and M.K. Upreti. 2018. Antimicrobial Susceptibility Pattern of GramNegative Bacterial Isolates from Raw Chicken Meat Samples. Tribhuvan University Journal of Microbiology. 6:89-95. file:///C:/Users/MY\%20PC/ Downloads/26590-Article\%20Text-80970-1-1020200107\%20(1).pdf

15. Gwida, M., H. Hotzel, L. Geue and H. Tomaso. 2014. Occurrence of Enterobacteriaceae in Raw
Meat and in Human Samples from Egyptian Retail Sellers. International Scholarly Research Notices, 1: 6. https://doi.org/10.1155/2014/565671

16. Happy, A.H., M.G. Alam, S. Mahmud, M.A.S. Imran, M.H. Rony, M.A.A. Azim, M.M. Islam, M.K.D. Sarker, P. Akter, G.C. Mondol, T. Hossain, M.M. Rahman, M.M. Islam, A. Roy, S. Das, M.R. Ahmed and M.E. Uddin. 2018. Isolation, Identification \& Characterization of Gram -Negative Bacteria from Popular Street Food (Chotpoti) at Savar Area, Dhaka, Bangladesh. Open Access Library Journal.5:1-11. https://doi.org/10.4236/oalib.1104986

17. Harsojo, H. and S.Y. Sari. 2015. Bacterial diversity in buffalo meat and bowel meat from traditional market and the sensitivity of some bacteria to irradiation and antibiotics. 4(2): 79 - 85. DOI - https://doi. org/10.17146/aij.2015.381

18. Kandeepan, G., A.S.R. Anjaneyulu, N. Kondaiah and S.K. Mendiratta. 2010. Quality of buffalo meat keema at different storage temperature. African Journal of Food Science 4: 410-417.

19. King, A. and Brown D.F.J. 2001. Quality Assurance of Antimicrobial Susceptibility testing by disc diffusion. Journal of Antimicrobial Chemotherapy 48: 71- 76.

20. Lawrie, R.A. and D.A. Ledward. 2006. Lawrie's meat science (7th edition) Cambridge: Wood Head Publishing Ltd. Pp 1-10.

21. Morshidy, A. and S. Roushdy. 1983. Studies on imported frozen meat. Zgazig Vet J 7:394-403.

22. Prathab, A.G. and C. Lalitha. 2012. Microbiological surveillance of air quality in operation theatrescomparison of the conventional settle plate techniques vs use of an air sampling device. J Evol Med Dent Sci 1:371.

24. Sharma, K.P. and U.K. Chattopadhyay. 2015. Assessment of Microbial load of raw meat Samples sold in the Open Markets of the city of Kolkota. Journal of Agriculture and Veterinary 8: 24-27. DOI: 10.9790/2380-08312427.

25. Siddiqui, M. and M.A. Khan. 2018. Comparative study on quality evaluation of buffalo meat slices incorporated with finger millets, oats and chickpeas. Journal of Animal research. 8(1): 117-123. DOI: 10.30954/2277-940X.2018.00150.19.

26. Shrestha, A., A.M. Bajracharya, H. Subedi, R.S. Turha, S. Kafle, S. Sharma and D.K. Chaudhary. 
2017. Multidrug resistance and extended-spectrum beta lactamase producing Gram-negative bacteria from chicken meat in Bharatpur Metropolitan, Nepal. B.M.C. Res Notes 10: 1-5.

27. Williams, K.P., J.J. Gillespie, B.W.S. Sobral, E.K. Nordberg, E.E. Snyder, J.M. Shallom and A.W.
Dickerman. 2010. Phylogeny of Gamma proteobacteria. Journal of Bacteriology 192: 2305-2314.

28. Vanderlinde, P.B., B. Shay and J. Murray. 1999. Microbiological status of Australian of sheep meat. Journal of Food Protection 62: 380-385. 